\title{
A Continuous Culture Study of Growth of Bacillus cereus T
}

\author{
By DON P. BOUDREAUX† AND V. R. SRINIVASAN* \\ Department of Microbiology, Louisiana State University, Baton Rouge, Louisiana 70803, \\ U.S.A.
}

(Received 8 April 1980; revised 24 June 1980)

\begin{abstract}
Growth of an oligosporogenic strain of Bacillus cereus $\mathrm{T}$ was studied in continuous culture. The maximum specific growth rate obtained was $0.47 \mathrm{~h}^{-1}$. RNA content increased linearly with increasing growth rate. Protein content decreased at high growth rates, but the DNA content of the culture was not affected by the growth rate. Activities of enzymes involved in glutamate utilization and energy production increased with increasing growth rate. The maximum specific activity for all enzymes assayed was obtained at a dilution rate of about $0.30 \mathrm{~h}^{-1}$. Changing the concentration of zinc or manganese in the medium by as little as $10^{-7} \mathrm{M}$ from the concentration optimum for growth caused a significant reduction in the steady-state bacterial population. Zinc appeared to affect the efficiency of conversion of substrate to biomass. Manganese was very toxic at concentrations slightly above the concentration optimum for a specific growth rate.
\end{abstract}

\section{INTRODUCTION}

The majority of studies on the control of spore formation have been performed in batch culture. These studies used media which were designed to give efficient sporulation; they were poorly optimized with respect to requirements necessary for vegetative growth. Investigations conducted under constant conditions which are optimum for either growth or sporulation may give better insight into the processes of growth and sporulation. One, and possibly the best, method by which these parameters can be achieved is by continuous culture. Dawes \& Thornley (1970) demonstrated that differentiation could be studied under the conditions imposed by continuous culture. The main shortcomings of continuous culture studies of differentiating organisms have been (i) the inability to grow the organisms at rates approaching the maximum specific growth rate and (ii) the selection of sporulation phase mutants. These problems are interrelated because the selection of sporulation mutants is most pronounced at slow growth rates. At slow growth rates a portion of a sporogenic culture will initiate the sporulation process. These sporulating cells do not divide and therefore do not contribute to the maintenance of the population. Sporulation mutants with lesions in late function spore genes (spoIV) similarly do not divide or contribute to population maintenance. Sporulation mutants altered early in the sporulation cycle $(s p o O)$ are enriched for because they can reverse early sporulation processes and resume vegetative growth. At fast growth rates (approaching the maximum specific growth rate) selection of mutants in sporulationspecific genes is minimum because any cell which can no longer divide is quickly removed from the culture. Development of a medium which will allow growth of the culture at rates approaching the maximum specific growth rate may go a long way towards solving the problem of mutant selection.

We have developed a medium for the growth of an oligosporogenic strain of Bacillus cereus $\mathrm{T}$. This medium allows growth under conditions of glucose limitation to a maximum

$\dagger$ Present address: Laboratory of Molecular Biology, National Institute of Neurological and Communicative Disorders and Stroke, Bethesda, Maryland 20205, U.S.A. 
specific growth rate of $0.47 \mathrm{~h}^{-1}$. In batch culture the oligosporogenic strains and the sporogenic parent exhibit the same growth rates and enzyme activities. During the development of this medium we observed extreme sensitivity to the concentration of various trace metals. The importance of trace metals for vegetative growth has previously been dismissed as not critical (Weinberg, 1970). The results presented in this report show that alterations in medium trace metal content greatly affect the yield of the culture.

\section{METHODS}

Organism. A variant strain of Bacillus cereus T was isolated by the method of Holliday (1956). This strain was designated $\mathrm{Sp}^{+}$. An oligosporogenic mutant of this strain was isolated from a chemostat culture of the sporogenic strain and designated $\mathrm{OSp}$.

Medium. A defined medium (GG) was designed from experiments conducted in continuous culture (Summers et al., 1979). The medium contained $1.1 \times 10^{-2} \mathrm{M}$-glucose, $1.5 \times 10^{-2} \mathrm{M}$-glutamate, $4.5 \times 10^{-3} \mathrm{M}-\left(\mathrm{NH}_{4}\right)_{2} \mathrm{SO}_{4}, 1.0 \times$ $10^{-2} \mathrm{M}-\mathrm{K}_{2} \mathrm{HPO}_{4}, 4.0 \times 10^{-4} \mathrm{M}-\mathrm{NaH}_{2} \mathrm{PO}_{4}, 4.92 \times 10^{-4} \mathrm{M}-\mathrm{MgCl}_{2}, 2.04 \times 10^{-5} \mathrm{M}^{-} \mathrm{CaCl}_{2}, 4.0 \times 10^{-10} \mathrm{M}^{-} \mathrm{CuSO}_{4}$, $1.69 \times 10^{-8} \mathrm{M}_{-} \mathrm{CoCl}_{2}, 5.10 \times 10^{-7} \mathrm{M}^{-} \mathrm{MnCl}_{2}, 3.3 \times 10^{-6} \mathrm{M}^{-\mathrm{ZnSO}_{4}}$ and $1.8 \times 10^{-6} \mathrm{M}^{-\mathrm{FeSO}_{4}}$. This medium allowed cultivation of the OSp strain under conditions of glucose limitation to a critical dilution rate of $0.47 \mathrm{~h}^{-1}$. Strains were maintained on plates of either $0.8 \%(\mathrm{w} / \mathrm{v})$ nutrient agar supplemented with $0.2 \%(\mathrm{w} / \mathrm{v})$ yeast extract or GG agar.

Unless otherwise noted, dilutions were prepared in a buffer of $0.15 \mathrm{M}-\mathrm{NaCl}, 0.05 \mathrm{M}$-Tris and $5 \times 10^{-3} \mathrm{M}$-EDTA at $\mathrm{pH} 7.5$ (STE buffer).

Cultivation. Batch cultures were prepared by inoculating $25 \mathrm{ml} \mathrm{GG}$ medium with either heat-shocked spores $\left(80^{\circ} \mathrm{C}, 30 \mathrm{~min}\right)$ or vegetative cells obtained from 24 to $36 \mathrm{~h} \mathrm{GG}$ agar plates. Following $16 \mathrm{~h}$ incubation at $23{ }^{\circ} \mathrm{C}$ the cultures were incubated at $34{ }^{\circ} \mathrm{C}$ until the $A_{600}$ reached 1.5 . [When spores were used $0.05 \%(\mathrm{w} / \mathrm{v})$ yeast extract was added to aid germination: no yeast extract was added in any subsequent transfers.l This culture was diluted 1 in 10 with fresh medium and incubated at $34^{\circ} \mathrm{C}$ until the $A_{600}$ reached 1.5 and then used to inoculate the chemostat or diluted 1 in 10 into side-arm flasks for studies on batch growth.

The chemostat consisted of a 11 flask with a $500 \mathrm{ml}$ working volume. The temperature was maintained at $34{ }^{\circ} \mathrm{C}$ by a constant temperature bath. The culture was agitated with a magnetic stirrer and aerated by sparging with filtered air at $750 \mathrm{ml} \mathrm{min}^{-1}$. The $\mathrm{pH}$ was maintained at 7.0 by automatic addition of $0.5 \mathrm{M}-\mathrm{NaOH}$.

Care was taken to avoid precipitation during the preparation of the medium. The medium was prepared twofold concentrated in two 401 carboys containing sterile water and sufficient concentrated $\mathrm{HCl}$ to give a final $\mathrm{pH}$ of 2.0. To one carboy was added sterile carbon, nitrogen and phosphorus sources. The other carboy contained the complement of trace metals. The medium was delivered from the two carboys to the growth vessel in equal volumes by a peristaltic pump (Harvard Apparatus, Millis, Mass., U.S.A.). A detailed description of the design and operation of the chemostat has been presented elsewhere (Summers et al., 1979).

After any change in the system, either due to sampling or change in medium composition, the culture was allowed a minimum of 10 residence times to re-establish a steady state.

Methods of sampling and assay. Samples of approximately $100 \mathrm{ml}$ were taken as a single portion into a chilled fiask and used for all analytical determinations.

A $20 \mathrm{ml}$ portion was immediately added to $20 \mathrm{ml}$ cold $10 \%(\mathrm{w} / \mathrm{v})$ trichloroacetic acid and held at $0{ }^{\circ} \mathrm{C}$ for $15 \mathrm{~min}$. The cells were harvested by centrifugation, resuspended in $2 \mathrm{ml} 0.5 \mathrm{M}-\mathrm{HClO}_{4}$ and stored at $-20{ }^{\circ} \mathrm{C}$. This sample was used for determination of cellular RNA, DNA and protein.

The cells from three further $10 \mathrm{ml}$ portions of the chilled sample were harvested by centrifugation $\left(8000 \mathrm{~g}, 10 \mathrm{~min}, 4^{\circ} \mathrm{C}\right)$. The supernatants were stored at $-20^{\circ} \mathrm{C}$ and used for determination of residual nutrients. The cells were washed twice with distilled water and dried to constant weight at $80^{\circ} \mathrm{C}$ for determination of dry weight.

For enzyme determinations, the cells from $40 \mathrm{ml}$ of the chilled sample were harvested by centrifugation $(8000 \mathrm{~g}$, $10 \mathrm{~min}, 4^{\circ} \mathrm{C}$ ). The cells were washed twice with cold STE buffer, resuspended in $10 \mathrm{ml}$ STE buffer and broken by ultrasonic disruption. Cell debris was removed by centrifuging $\left(8000 \mathrm{~g}, 10 \mathrm{~min}, 4^{\circ} \mathrm{C}\right)$. The supernatant was kept in an ice bath until used for determination of enzyme activities.

Culture turbidity was determined using a Klett-Summerson colorimeter with a no. 66 red filter. Samples were diluted to give a reading of between 25 and 100 Klett units to ensure linearity.

Glucose, phosphate and ammonia concentrations were determined by the methods of Miller (1959), Fisk \& Subbarow (1925) and Weatherburn (1967), respectively. Prior to determination of residual glutamate, unused ammonia was removed by evaporating $5 \mathrm{ml}$ of sample to dryness under alkaline conditions ( $\mathrm{pH} \mathrm{8.0)}$. The residue was resuspended to the original volume in distilled water and the glutamate was assayed by the dinitrophenylation 
reaction (Ghuysen et al., 1966). The amount of a given substrate used was determined by subtracting the amount present in the spent medium from the amount assayed to be present in the complete medium.

The DNA and RNA contents of the cells were determined by the diphenylamine and orcinol reactions, respectively, as described by Schneider (1956). The protein concentration was determined by the Lowry method. Fumarase (EC 4.2.1.2) activity was determined by the method of Kanarek \& Hill (1964). Malic dehydrogenase (EC1.1.1.37) and alkaline phosphatase (EC 3.1.3.1) were determined as described by Yoshida (1965) and Garen \& Levinthal (1960), respectively. Glutamic-oxaloacetic transaminase (GOT; L-aspartate:2-oxoglutarate aminotransferase; EC 2.6.1.1) and glutamic-pyruvic transaminase (GPT; L-alanine:2-oxoglutarate aminotransferase; EC 2.6.1.2) activities were assayed as described in Sigma technical bulletin no. 55-UV.

\section{RESULTS}

\section{Isolation of strain $O S p$}

Routine plating of chemostat cultures of the $\mathrm{Sp}^{+}$strain on GG plates demonstrated two colony types. Strain $\mathrm{Sp}^{+}$produced small, convex, mucoid colonies. Phase contrast microscopy showed that these colonies contained more than $95 \%$ free spores after $48 \mathrm{~h}$ at $34^{\circ} \mathrm{C}$. The second colony type (OSp) was larger, non-mucoid and essentially free of spores after similar incubation. The OSp strain comprised $50 \%$ of the population of a chemostat culture $\left(D=0.29 \mathrm{~h}^{-1}\right)$ after $8 \mathrm{~d}$ when the culture was inoculated with the $\mathrm{Sp}^{+}$strain. Conversely, when the chemostat was inoculated with strain OSp, no $\mathrm{Sp}^{+}$cells could be detected after $10 \mathrm{~d}\left(D=0.29 \mathrm{~h}^{-1}\right)$ by plate counts on GG agar. The growth rates of the two strains in batch culture on GG medium supplemented with $0.02 \%$ yeast extract were identical throughout the vegetative phase and diverged only slightly during differentiation (Fig. 1). The $\mathrm{Sp}^{+}$strain sporulated completely after $24 \mathrm{~h}$. Strain OSp produced only $0 \cdot 1 \%$

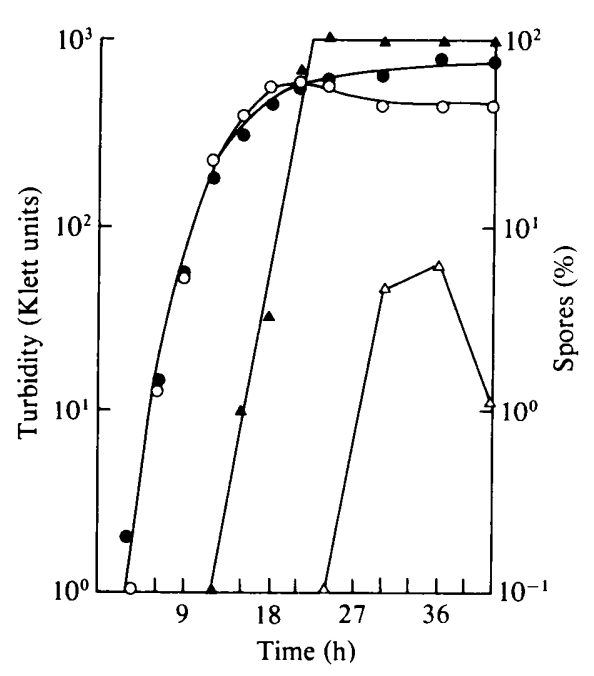

Fig. 1

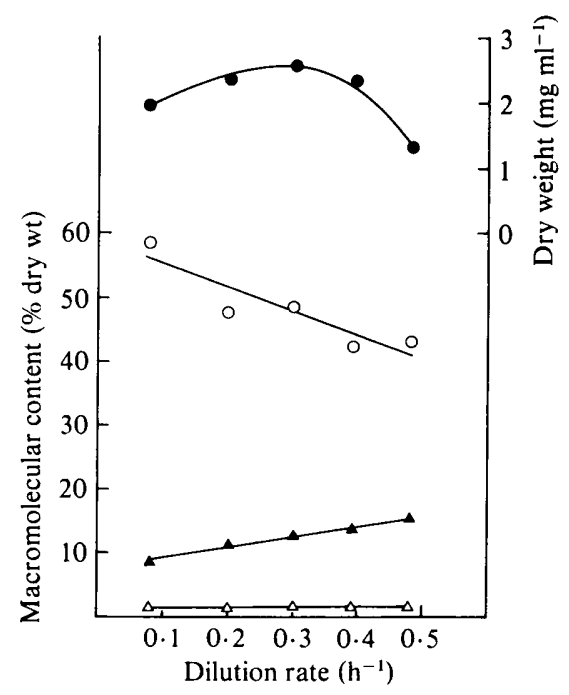

Fig. 2

Fig. 1. Growth $(\Theta, O)$ and percentage of spores $(\Delta, \Delta)$ for the sporogenic $(O, \Delta)$ and oligosporogenic $(O, \Delta)$ strains grown in batch culture in GG medium supplemented with $0.02 \%$ yeast extract. Viable and spore titres were determined by plating on GG agar plates; heat-resistant spores were detected by heating dilution tubes to $80^{\circ} \mathrm{C}$ for $30 \mathrm{~min}$ before plating.

Fig. 2. Macromolecular composition of strain OSp in a continuous culture at various growth rates. Samples were taken after 10 residence times at the indicated dilution rate. Glucose was the limiting nutrient at all dilution rates except $D=0.48 \mathrm{~h}^{-1}$; at this dilution rate no steady state could be achieved $\left(\mu_{\max }=0.47 \mathrm{~h}^{-1}\right)$. The macromolecular content is expressed as a percentage of the cellular dry weight $\left[\%\right.$ dry $w \mathrm{t}=100 \times\left(\mathrm{mg}\right.$ macromolecule $\left.\mathrm{ml}^{-1}\right) /\left(\mathrm{mg}\right.$ cell dry $\left.\left.\mathrm{wt} \mathrm{ml}^{-1}\right)\right]$. Dry weight $(\mathrm{O})$, protein (O), RNA ( $\Delta)$ and DNA $(\triangle)$. 
Table 1. Carbon and nitrogen consumed by strain OSp in a chemostat at different dilution rates

\begin{tabular}{|c|c|c|c|c|c|c|c|}
\hline \multirow{2}{*}{$\begin{array}{c}\text { Dilution } \\
\text { rate } \\
\left(h^{-1}\right)\end{array}$} & \multirow{2}{*}{$\begin{array}{c}\text { Dry } \\
\text { weight } \\
\left(\mathrm{g} \mathrm{l}^{-1}\right)\end{array}$} & \multicolumn{3}{|c|}{ Carbon consumed $\left(\mathrm{g}^{-1}\right) \ddagger$} & \multicolumn{3}{|c|}{ Nitrogen consumed $\left(\mathrm{g} \mathrm{l}^{-1}\right)$} \\
\hline & & $\begin{array}{l}\text { From } \\
\text { glucose }\end{array}$ & $\begin{array}{c}\text { From } \\
\text { glutamate }\end{array}$ & Total & $\begin{array}{c}\text { From } \\
\text { glutamate }\end{array}$ & $\begin{array}{c}\text { From } \\
\left(\mathrm{NH}_{4}\right)_{2} \mathrm{SO}_{4}\end{array}$ & Total \\
\hline $0.11^{*}$ & 1.898 & 0.792 & 0.816 & 1.608 & 0.191 & -0.008 & $0 \cdot 183$ \\
\hline $0.23^{*}$ & $2 \cdot 140$ & 0.792 & 0.819 & 1.611 & 0.192 & 0.027 & 0.219 \\
\hline $0 \cdot 28^{*}$ & $2 \cdot 140$ & 0.792 & 0.821 & 1.613 & 0.192 & 0.040 & 0.232 \\
\hline $0 \cdot 38^{*}$ & 2.088 & 0.792 & 0.816 & 1.608 & 0.191 & 0.064 & 0.255 \\
\hline $0.46^{*}$ & 1.723 & 0.792 & 0.683 & 1.475 & $0 \cdot 160$ & 0.064 & $0 \cdot 224$ \\
\hline $0.51 \dagger$ & $0 \cdot 131$ & 0.206 & 0.115 & $0 \cdot 321$ & 0.027 & 0.000 & 0.027 \\
\hline
\end{tabular}

\footnotetext{
* Glucose-limited at steady state.

† Sample taken after 24 residence times at this growth rate.

¥When no glucose could be detected in the spent medium it was assumed that glucose consumption was complete.
}

spores after $24 \mathrm{~h}$ and a maximum of $6 \%$ after $36 \mathrm{~h}$. Both strains were sensitive to the phage $\phi \mathrm{CL}$, a phage lytic to $B$. cereus T. Continuous culture studies were conducted with strain OSp.

\section{Effect of growth rate on the physiology of strain OSp in continuous culture}

Strain OSp was grown under conditions of glucose limitation in GG medium over a wide range of dilution rates. The maximum growth rate obtained with glucose limitation at steady state was $0.47 \mathrm{~h}^{-1}$. This agrees well with the maximum growth rate obtained in batch culture with the same medium $\left(\mu_{\max }=0.46 \mathrm{~h}^{-1}\right)$. At growth rates slightly above this value a slow wash-out began and a glucose-limited steady state could not be re-established.

The RNA content of the culture increased linearly with growth rate (Fig. 2). DNA content was constant over all growth rates examined. The protein content of the cells decreased as the growth rate increased.

The carbon and nitrogen required for growth could each be derived from two sources. Table 1 presents results for the utilization of these substrates expressed as carbon or nitrogen used per litre of medium. Glucose was the limiting nutrient at all dilution rates examined up to the critical dilution rate. Glutamate utilization was constant at most dilution rates, but decreased somewhat as the critical dilution rate was approached. The total nitrogen removed from the medium increased as the growth rate increased to a maximum at $D=0.38 \mathrm{~h}^{-1}$. This could occur by increasing the use of nitrogen from ammonium sulphate at faster growth rates or by more efficient scavenging of the nitrogen derived from glutamate metabolism. The culture did not attain glucose limitation at a growth rate of $0.10 \mathrm{~h}^{-1}$ if ammonium sulphate was omitted from the medium (not shown). Additionally, in the complete medium at a dilution rate of $0.11 \mathrm{~h}^{-1}$ there was a slight increase in the ammonium ion concentration in the medium (Table 1). These observations suggest that variable glutamate-nitrogen use is more likely. Two transaminases involved in glutamate utilization were monitored at various growth rates in order to investigate changes in glutamate utilization. Both GOT and GPT activities increased as the growth rate increased from $D=0.08 \mathrm{~h}^{-1}$ to $D=0.30 \mathrm{~h}^{-1}$ (Table 2). The total transaminase activity (GOT plus GPT) was maximum near a dilution rate of $0.30 \mathrm{~h}^{-1}$. At higher dilution rates there was a decrease in transaminase activity. These results, together with those for nitrogen utilization presented above, suggest that the nitrogen derived from glutamate metabolism at slow growth rates is not efficiently used and is lost by the cell as ammonium ions.

Batch culture studies suggest that various citric acid cycle enzymes are not active in 
Table 2. Specific activity of selected enzymes of strain OSp at various dilution rates

\begin{tabular}{|c|c|c|c|c|c|}
\hline \multirow[b]{3}{*}{ Enzyme } & \multicolumn{5}{|c|}{ Specific activity $\left[\mu \mathrm{mol} \min ^{-1}(\mathrm{mg} \text { protein })^{-1}\right]$} \\
\hline & \multicolumn{5}{|c|}{ Dilution rate $\left(\mathrm{h}^{-1}\right)$} \\
\hline & $0.08^{*}$ & $0 \cdot 20^{*}$ & $0 \cdot 30^{*}$ & $0.39^{*}$ & 0.52 \\
\hline Glutamic-oxaloacetic transaminase & $62 \cdot 4$ & $203 \cdot 8$ & $256 \cdot 3$ & $195 \cdot 1$ & $181 \cdot 4$ \\
\hline Glutamic-pyruvic transaminase & $24 \cdot 24$ & $23 \cdot 86$ & $42 \cdot 53$ & $48 \cdot 86$ & 48.48 \\
\hline Fumarase & 0.038 & 0.338 & 0.495 & 0.445 & 0.378 \\
\hline Malic dehydrogenase & $0 \cdot 172$ & 0.322 & 0.332 & $0 \cdot 270$ & 0.260 \\
\hline
\end{tabular}

Table 3. Comparison of selected enzyme activities of $\mathrm{Sp}^{+}$and $\mathrm{OSp}$ cells grown in batch culture

Cells were grown to a turbidity of 100 Klett units. Cell extracts were prepared as described in Methods.

\begin{tabular}{lcc}
\multicolumn{1}{c}{ Enzyme } & \multicolumn{1}{c}{$\begin{array}{c}\text { Specific activity } \\
{\left[\mu \mathrm{mol} \mathrm{min}^{-1}\left(\mathrm{mg}^{2} \text { protein }\right)^{-1}\right]}\end{array}$} \\
\cline { 2 - 3 } Fumarase & 0.179 & $\mathrm{OSp}$ \\
Malic dehydrogenase & 0.167 & 0.087 \\
Glutamic-oxaloacetic transaminase & 122.9 & 0.117 \\
Glutamic-pyruvic transaminase & 11.57 & 182.1 \\
Alkaline phosphatase & 0.039 & 13.15 \\
& & 0.046
\end{tabular}

vegetative cells and are induced only after depletion of readily fermentable carbohydrates and/or the induction of sporulation (Srinivasan, 1965; Freese \& Fujita, 1976). If this assumption were correct, one would expect a decrease in the specific activities of fumarase and malic dehydrogenase with increasing growth rates. In batch culture both of these enzyme activities were shown to be higher during sporulation than during vegetative growth (Charba \& Nakata, 1977). The activities of both fumarase and malic dehydrogenase increased with increased growth rate to a maximum value at a dilution rate of $0.30 \mathrm{~h}^{-1}$ (Table 2). No alkaline phosphatase activity was observed over the range of dilution rates examined.

Since the frequency of conversion of $\mathrm{Sp}^{+}$to $\mathrm{OSp}$ was relatively high, enzyme assays could not be carried out with $\mathrm{Sp}^{+}$cells under conditions of continuous culture. The enzyme activities of the $\mathrm{Sp}^{+}$and $\mathrm{OSp}$ strains were therefore compared in extracts of cells grown in batch culture. As seen in Table 3, the enzyme activities in the two strains were similar. Alkaline phosphatase, not detected in chemostat cultures of strain OSp, was detected in extracts of both strains grown in batch culture. This is probably due to the physiological heterogeneity of cell types found in batch culture.

\section{Effect of trace metal concentration on growth}

Early in these studies we observed that a significant fluctuation in the population was caused by a slight alteration in the trace metal composition of the medium. We therefore examined the effect of trace metals on the growth of strain OSp. The chemostat was operated at a constant dilution rate of $0.40 \mathrm{~h}^{-1}$ as the concentration of the trace metal was varied, and fluctuations in turbidity, dry weight and nutrient utilization at steady state were monitored; the results of experiments with zinc and manganese are presented.

The dry weight of cells was dependent on the zinc concentration (Fig. 3). Maximum dry weight was obtained at a zinc concentration 10-fold lower than that necessary for glucose-limited growth at the maximum specific growth rate. The RNA content increased linearly with zinc concentration. Cellular DNA content was constant. The protein 


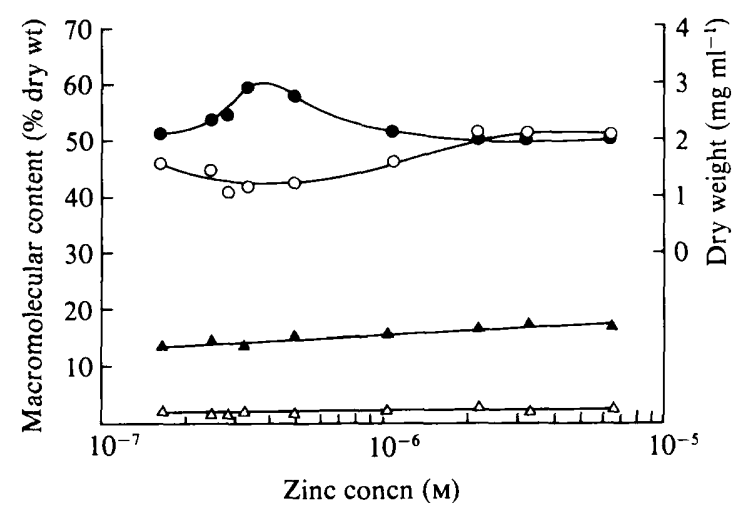

Fig. 3. Effect of zinc concentration on growth and macromolecular composition of strain OSp grown in a chemostat at a dilution rate of $0.40 \mathrm{~h}^{-1}$. Macromolecular content is expressed as in Fig. 2. Dry weight

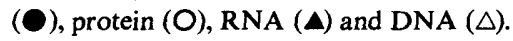

Table 4. Effect of zinc concentration on dry weight and nutrient consumption of strain OSp in a continuous culture at a growth rate of $0.40 \mathrm{~h}^{-1}$

$\begin{array}{cccccc}\begin{array}{c}\text { Zinc } \\ \text { concn } \\ (\mu \mathrm{M})\end{array} & \begin{array}{c}\text { Klett } \\ \text { units }\end{array} & \begin{array}{c}\text { Dry } \\ \text { weight } \\ \left(\mathrm{g}^{-1}\right)\end{array} & \begin{array}{c}\text { Carbon } \\ \text { consumed } \\ \left(\mathrm{g}^{-1}\right)\end{array} & \begin{array}{c}\text { Nitrogen } \\ \text { consumed } \\ \left(\mathrm{g} \mathrm{l}^{-1}\right)\end{array} & \begin{array}{c}\text { Phosphorus } \\ \text { consumed } \\ \left(\mathrm{g} \mathrm{l}^{-1}\right)\end{array} \\ 0.167 & 530 & 2.183 & 1.297^{*} & 0.139 & 0.060 \\ 0.248 & 570 & 2.338 & 1.495^{*} & 0.148 & 0.062 \\ 0.281 & 590 & 2.445 & 1.505^{*} & 0.141 & 0.063 \\ 0.330 & 690 & 2.915 & 1.539^{*} & 0.179 & 0.072 \\ 0.495 & 670 & 2.838 & 1.573^{*} & 0.192 & 0.078 \\ 1.100 & 550 & 2.150 & 1.566^{*} & 0.199 & 0.082 \\ 2.200 & 525 & 2.069 & 1.544^{*} & 0.197 & 0.081 \\ 3.300 & 510 & 2.033 & 1.529^{*} & 0.181 & 0.080 \\ 6.600 & 550 & 2.028 & 1.498^{*} & 0.174 & 0.080 \\ 16.500 & 550 & 2.043 & 1.474^{*} & 0.174 & 0.071 \\ & & & & & \end{array}$

concentration varied over the range of zinc concentrations tested with a pattern opposite to that of the dry weight. The observation that the maximum dry weight was not obtained at the zinc concentration needed for the optimum growth rate was interesting. This could be caused either by increased substrate utilization or by more efficient conversion of substrate to biomass at lower zinc concentrations. The amount of glucose used was constant at all zinc concentrations assayed (no residual glucose was detected in the spent medium). The increase in the utilization of the other substrates over the range of zinc concentrations monitored was not sufficient to account for the increased dry weight (Table 4). The enhanced yield must therefore be due to the increased efficiency with which substrate was metabolized.

Examination of the effect of manganese concentration on growth was conducted with zinc at the concentration which gave the maximum dry weight in the zinc studies (Table 4, $0.33 \mu \mathrm{M}$ ). Again, the dilution rate was maintained at $0.40 \mathrm{~h}^{-1}$. Slight alterations in the manganese concentration produced a significant variation in dry weight. In this case, however, substrate utilization closely followed the dry weight (Table 5). For manganese it appears that at concentrations below the optimum for growth the culture was limited by manganese availability and at concentrations slightly above the optimum the toxicity of manganese inhibited growth. The RNA content decreased linearly as the manganese 
Table 5. Effect of manganese concentration on dry weight and nutrient consumption of strain OSp in continuous culture at a growth rate of $0.40 \mathrm{~h}^{-1}$

\begin{tabular}{cccccc}
$\begin{array}{c}\text { Manganese } \\
\text { concn } \\
(\mu \mathrm{M})\end{array}$ & $\begin{array}{c}\text { Klett } \\
\text { units }\end{array}$ & $\begin{array}{c}\text { Dry } \\
\text { weight } \\
\left(\mathrm{g} \mathrm{I}^{-1}\right)\end{array}$ & $\begin{array}{c}\text { Carbon } \\
\text { consumed } \\
\left(\mathrm{g}^{-1}\right)\end{array}$ & $\begin{array}{c}\text { Nitrogen } \\
\text { consumed } \\
\left(\mathrm{g} \mathrm{l}^{-1}\right)\end{array}$ & $\begin{array}{c}\text { Phosphorus } \\
\text { consumed } \\
\left(\mathrm{g} \mathrm{l}^{-1}\right)\end{array}$ \\
0.051 & 103 & 0.41 & 0.650 & 0.177 & 0.007 \\
0.153 & 210 & 0.82 & 0.839 & 0.171 & 0.023 \\
0.255 & 780 & 3.24 & $1.625^{*}$ & 0.287 & 0.065 \\
0.383 & 740 & 3.09 & $1.654^{*}$ & 0.308 & 0.056 \\
0.510 & 680 & 3.09 & $1.618^{*}$ & 0.302 & 0.056 \\
1.020 & 565 & 2.59 & $1.540^{*}$ & 0.273 & 0.057 \\
& \multicolumn{5}{c}{ * Glucose-limited steady state. }
\end{tabular}

concentration was raised above the optimum concentration. DNA and protein concentrations were constant at all manganese concentrations tested (results not shown).

\section{DISCUSSION}

The results presented here demonstrate that the growth rate of a culture alters the physiological state of that culture. One other unexpected observation was that a slight alteration in the trace metal complement of the medium significantly altered primary metabolism.

At slow growth rates $\left(D \leqslant 0.11 \mathrm{~h}^{-1}\right)$ strain OSp could not use glutamate-derived nitrogen as the sole nitrogen source. The amount of nitrogen available from the metabolism of glutamate was sufficient to satisfy the requirements of the culture if it were efficiently assimilated. The enzymes needed for efficient glutamate-nitrogen utilization were not fully induced at slow growth rates. The decrease in nitrogen consumption observed near the critical dilution rate $\left(D=0.46 \mathrm{~h}^{-1}\right.$, Table 1$)$ paralleled the decrease in glutamate-carbon utilization at this growth rate. This is probably because at this fast growth rate the cell was unable to sustain a sufficient level of glutamate metabolism to supply its energy demand.

Previous reports (Hanson et al., 1963; Charba \& Nakata, 1977) have shown that in batch cultures of bacilli fumarase and malic dehydrogenase activities were very low at the end of vegetative growth and only during differentiation did the activities of these enzymes rise. These enzyme activities can be induced in continuous culture by increasing the growth rate. The similarity in the enzyme activities in the two strains grown in batch culture is an important observation and indicates that the regulation of these enzymes in the OSp strain is the same as that found in the $\mathrm{Sp}^{+}$strain and that they are not regulated by a sporulationspecific gene(s). It is more likely that their regulation is directly related to cellular energy demand rather than the availability of nutrients or the growth phase.

Weinberg (1970) has suggested that trace metal concentrations required for secondary metabolism may be three orders of magnitude higher than needed for growth. He reported that these elevated concentrations of trace metals do not interfere with vegetative growth. This concept is in contradiction to our findings. Slight $\left( \pm 10^{-7} \mathrm{M}\right)$ fluctuations of either zinc or manganese concentration altered the vegetative metabolism of the cell. The trace metal effect can be observed at growth rates lower than those presented, but the effect is not as striking. We have shown that by varying the trace metal content of the medium the efficiency of substrate utilization can be altered. This conversion of carbon and/or nitrogen to biomass is very efficient under optimum conditions (optimum ratio of trace metals for a particular growth rate).

The selection of mutants in chemostat culture has hampered the use of this technique in the study of sporulation. We chose to study the OSp strain due to its similarity to the parental 
strain with respect to growth and enzyme activities (Fig. 1, Table 3). The results for macromolecular content and nutrient utilization are typical of a glucose-limited steady-state culture. The system is in agreement with the model of Dawes \& Mandelstam (1969) for a differentiating organism in continuous culture. The problem of selection of sporulation mutants in continuous culture might be circumvented by operating at fast growth rates and by not operating the chemostat for extended periods. The potential of the chemostat in the study of differentiation should not be overlooked. The observations presented in this report should be useful in understanding the metabolism of bacilli in continuous culture and form a basis on which to build so that continuous culture techniques may be better used to study the technically more difficult problem of differentiation.

\section{REFERENCES}

Charba, J. F. \& Nakata, H. M. (1977). Role of glutamate in the sporogenesis of Bacillus cereus. Journal of Bacteriology 130, 242-248.

Dawes, I. W. \& Mandelstam, J. (1969). Biochemistry of sporulation of Bacillus subtilis 168 : continuous culture studies. In Proceedings of the 4th International Symposium on Continuous Culture of Microorganisms, pp. 157-162. Prague: Academia Publishing House of Czechoslovak Academy of Sciences.

Dawes, I. W. \& ThORNLEY, J. H. M. (1970). Sporulation in Bacillus subtilis. Theoretical and experimental studies in continuous culture systems. Journal of General Microbiology 62, 49-66.

Fisk, C. H. \& SubBarow, Y. (1925). The colorometric determination of phosphorus. Journal of Biological Chemistry 66, 375-400.

Freese, E. \& FujtTA, Y. (1976). Control of enzyme synthesis during growth and sporulation. In Microbiology 1976, pp. 164-184. Edited by D. Schlessinger. Washington, D.C.: American Society for Microbiology.

Garen, A. \& Levinthal, C. (1960). A fine-structure genetic and chemical study of the enzyme alkaline phosphatase of $E$. coli I. Purification and characterization of alkaline phosphatase. Biochimica et biophysica acta 38, 470-483.

GhuYSen, J. M., Tipper, D. T. \& Strominger, J. L. (1966). Enzymes that degrade bacterial cell walls. Methods in Enzymology 8, 685-699.

Hanson, R. S., Srinivasan, V. R. \& Halvorson, H. O. (1963). Biochemistry of sporulation. II. Enzymatic changes during sporulation of Bacillus cereus. Journal of Bacteriology 85, 45-50.
Holliday, R. (1956). A new method for identification of biochemical mutants of microorganisms. Nature, London 178, 987.

KANAREK, L. \& Hill, R. (1964). The preparation and characterization of fumarase from swine heart muscles. Journal of Biological Chemistry 239, 4202-4208.

Miller, G. L. (1959). Use of dinitrosalicylic acid reagent for determination of reducing sugar. Analytical Chemistry 30, 426-428.

SCHNEIDER, W. C. (1956). Determination of nucleic acids in tissues by pentose analysis. Methods in Enzymology 3, 680-684.

SRINIVASAN, V. R. (1965). Intracellular regulation of sporulation of bacteria. In Spores III, pp. 64-74. Edited by L. L. Campbell \& H. O. Halvorson. Ann Arbor, Mich: American Society for Microbiology.

Summers, R. J., Boudreaux, D. P. \& Srinivasan, V. R. (1979). Continuous cultivation as a method of apparent optimization of defined media for bacteria (Cellulomonas and Bacillus sp.). Applied and Environmental Microbiology 38, 66-71.

Weatherburn, M. W. (1967). Phenol-hypochlorite reaction for determination of ammonia. Analytical Chemistry 39, 971-974.

WEINBERG, E. D. (1970). Biosynthesis of secondary metabolites. Roles of trace metals. Advances in Microbial Physiology 4, 1-44.

YoshidA, A. (1965). Purification and chemical characterization of malate dehydrogenase of Bacillus subtilis. Journal of Biological Chemistry 240, 1113-1117. 